\title{
Preparation and Characterization of PVA/PASA-PVA/PDDAB Bipolar Membrane
}

\author{
Heriberto Espinoza-Gómez, *,a Lucía Z. Flores-López, ${ }^{b}$ Eduardo Rogel-Hernández ${ }^{c}$ \\ and Manuel Martínez ${ }^{a}$
}

${ }^{a}$ Facultad de Ciencias Químicas e Ingeniería, Universidad Autónoma de Baja California, Calzada Tecnológico 14418, 22348 Tijuana-B.C., México

${ }^{b}$ Centro de Graduados e Investigación del Instituto Tecnológico de Tijuana, Blvd. Industrial s/n Tijuana, B.C. México

\begin{abstract}
Membranas bipolares foram preparadas pela junção de membranas de troca catiônica e aniônica. Para a preparação da camada seletiva a cátions, soluções aquosas de PVA [poli(vinil álcool)] e PASA [poli(sódio anatolesulfonato)], em que a razão PVA/PASA foi modificada para o controle da densidade de carga da membrana, foram preparadas para produzir membranas carregadas negativamente. Estas membranas foram tratadas a $100{ }^{\circ} \mathrm{C}$ por 45 min e reticuladas em solução aquosa contendo $10 \%$ de $\mathrm{Na}_{2} \mathrm{SO}_{4}, 1,5 \%$ de $\mathrm{H}_{2} \mathrm{SO}_{4}$ e $0,5 \%$ de glutaraldeído, a fim de controlar a quantidade de água no gel das membranas. As camadas seletivas a ânions foram preparadas pela dispersão de uma solução de PVA e PDDAB [poli(brometo de dialildietilamônio)] em DMF, em que a razão PVA/PDDAB foi modificada para o controle da densidade de carga na membrana. A resistência elétrica de membranas bipolares preparadas por esta metodologia aumentou ligeiramente, enquanto a seletividade diminuiu e sua perme-seletividade não mudou com o póstratamento ácido ou alcalino.
\end{abstract}

Bipolar membranes (BMP) were prepared by bonding together separate anion and cation exchange membrane. For the preparation of the cation selective layer, aqueous solution of PVA [poly(vinyl alcohol)], and PASA [poly(anetholesulfonic acid sodium salt)], where the ratio of PVA/PASA was changed for the control of the membrane charge density, were cast for negatively charged membranes. These membranes were annealed at $100{ }^{\circ} \mathrm{C}$ for $45 \mathrm{~min}$ and cross-linked in an aqueous solution containing $10 \% \mathrm{Na}_{2} \mathrm{SO}_{4}, 1.5 \% \mathrm{H}_{2} \mathrm{SO}_{4}$, and $0.5 \%$ glutaraldehyde in order to control water content of the gel membranes. The anion selective layers were prepared by dispersing a solution of PVA and PDDAB [poly(diallyldiethylammonium bromide)] in DMF, where the ratio of PVA/PDDAB was changed for the membrane charge density control. The electrical resistance of BMP formed by this methodology was slightly increased while the selectivity decreased, while their permselectivity did not change with the acid or alkaline post-treatment.

Keywords: bipolar membrane, PVA/PASA, PVA/PDDAB, bipolar membrane characterization

\section{Introduction}

The bipolar membrane (BMP) is an ion-exchanging membrane composed of two ion-exchange regions of opposite polarity in series. ${ }^{1,2}$ BMP consists of a layered structure involving a cation selective membrane joined to an anion selective membrane. They can be of the sandwichlike structure involving a negatively charge layer, $\mathrm{N}$, and a positive charged layer, $\mathrm{P}$, pressed together. ${ }^{3-5} \mathrm{BMP}$ systems were considered in the past as simple models for biological systems, ${ }^{6-9}$ acid and base production, ${ }^{10-15}$ and treatment of

*e-mail: jhespinoza@uabc.mx saltwater effluents..$^{14,16-18}$ The characterization of BMP has been carried out for aqueous solutions systems by studying the current-voltage curve, ${ }^{4,19-28}$ membrane potential, ${ }^{29-33}$ and ac impedance spectra. ${ }^{34-39}$

Bipolar membrane preparation can be formed by laminating (heat-pressing or gluing) an anion exchange membrane and a cation one, back to back; introducing positively charged fix groups and negatively charged ones to different sides of a neutral film, or casting a cation (or anion) exchange polyelectrolyte solution on a commercial anion (or cation) exchange membrane. ${ }^{40}$ The ideal BMP should have high permselectivity, low electrical resistance and water splitting voltage drop, high current efficiency, 
good chemical and mechanical stability, long lifetime, and no "balloonig". ${ }^{40,41}$

In the laminated BMP, the anion and cation selective layer must not be so close to each other that they can interpenetrate. It seems that the interpenetration might take place in the high resistance bipolar films which are formed by pressing together. It has been speculated that the high electrical resistance of the membrane and the apparent fusion of the two fixed charged regions, could be due to the anion and cation exchange films interpenetrating each other, under the action of the strong electrostatic attractive force between the oppositely charged layers. ${ }^{42}$ Generally most of the overpotential for BMP formed by pressing together separate anion and cation selective films appears across the interface. ${ }^{10,42-44}$

It is evident from the foregoing that the major problem in preparing low resistance BMP which are laminates of conventional anion and cation exchange membrane is to obtain an interface for which the overvoltage is low for currents in the commercial range $\left(c a .100 \mathrm{~mA} \mathrm{~cm}^{-2}\right)$. The main objective of the work described in this paper was the development of a laminated BMP with good chemical stability, high permselectivity, and low electrical resistance.

\section{Experimental}

\section{Membrane preparation}

Bipolar membranes were prepared by bonding together separate anion and cation exchange films or membranes. The two monopolar membrane of opposite selectivity were fused together in a hydraulic press at $160^{\circ} \mathrm{C}$ at a pressure of $2.76 \mathrm{MPa}$ to form a two ply membrane structure.

\section{Preparation of the cation selective layer}

For the preparation of the cation selective layer, aqueous solution of a mixture of poly(vinyl alcohol), (PVA Sigma-Aldrich, Mw 146,000-186,000), and poly(anetholesulfonic acid sodium salt), (PASA, Fluka) (Figure 1), where the ratio of PVA/PASA was changed for the control of the membrane charge density, were cast for negatively charged membranes. These membranes were annealed at $100{ }^{\circ} \mathrm{C}$ for $45 \mathrm{~min}$ and cross-linked in an aqueous solution containing $10 \% \mathrm{Na}_{2} \mathrm{SO}_{4}, 1.5 \% \mathrm{H}_{2} \mathrm{SO}_{4}$, and $0.5 \%$ glutaraldehyde in order to control water content of the gel membranes.

\section{Preparation of the anion selective layer}

The anion selective layers were prepared by dispersing a solution of PVA and poly(diallyldiethylammonium bromide), (PDDAB, Fluka) (Figure 1) in DMF, where the ratio of PVA/PDDAB was changed for the membrane charge density control.

In both types of membranes, were utilized PAA like copolimer, given their mechanical properties and due to that the difusion coefficients of salt type 1-1 through this polymer, are known..$^{45}$

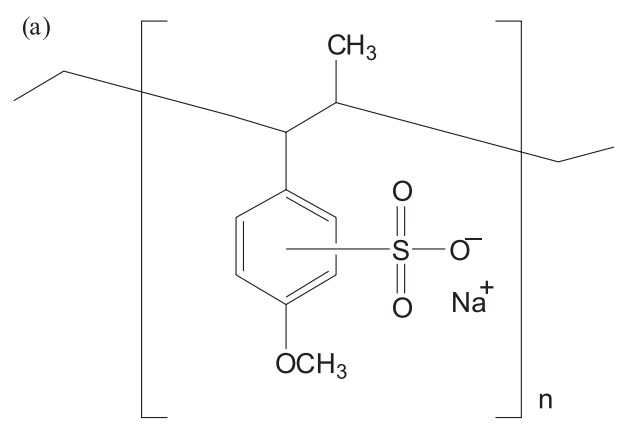

(b)

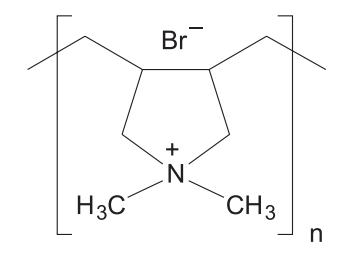

Figure 1. Chemical structure of the repetitive unit of the polymers utilized. (a) poly(anetholesulfonic acid sodium salt), (b) poly(diallyldiethylammonium bromide).

\section{Membrane characterization}

Membranes prepared by the above described procedures were characterized in terms of their ion-exchange capacity, their electrical resistance, their swelling deionized water, their permselectivity, their water splitting capacity, and their chemical stability.

\section{Determination of the membrane ion-exchange capacities}

The ion-exchange capacity of the membranes was determined by titrating the fixed $-\mathrm{RSO}_{3}-\left(\mathrm{RSO}_{3}^{-}\right)$ and $-\mathrm{R}_{4} \mathrm{~N}^{+}\left(-\mathrm{NR}_{3}{ }^{+}\right)$groups with $0.1 \mathrm{~mol} \mathrm{~L}^{-1} \mathrm{NaOH}$ or $0.1 \mathrm{~mol} \mathrm{~L}^{-1} \mathrm{HC} 1$, respectively, against methyl red or phenolphthalein. For these tests, cation- and anionexchange membranes were equilibrated for $24 \mathrm{~h}$ in $1 \mathrm{~mol} \mathrm{~L}^{-1} \mathrm{NaOH}$ or $1 \mathrm{~mol} \mathrm{~L}^{-1} \mathrm{HCI}$, respectively, and then rinsed for $3 \mathrm{~h}$ with deionized water. The ion-exchange capacity of samples was then determined by titration with $0.1 \mathrm{~mol} \mathrm{~L}^{-1} \mathrm{HCI}$ or $0.1 \mathrm{~mol} \mathrm{~L}^{-1} \mathrm{NaOH}$, respectively. The samples were then dried and the ion-exchange capacity calculated for the dry membrane.

\section{Determination of the membrane swelling}

To determine the degree of swelling, membrane samples were equilibrated for 3 days in deionized water. After 
removing the surface water from the sample, the weight of the wet sample was determined. The sample was then dried at $75^{\circ} \mathrm{C}$ over phosphorous pentoxide until a constant weight was obtained. The degree of swelling was determined from the weight difference between the wet $\left(\mathrm{m}_{\text {wet }}\right)$ and dry $\left(\mathrm{m}_{\text {dry }}\right)$ membrane according to equation 1.

$\operatorname{swelling}(\%)=\frac{\mathrm{m}_{\text {wet }}-\mathrm{m}_{\mathrm{dry}}}{\mathrm{m}_{\mathrm{dry}}} \times 100$

\section{Determination of the membrane electrical resistance}

The electrical resistance of the membranes was determined by conductivity measurements in a cell, shown schematically in Figure 2. The cell consists of two wellstirred chambers separated by the membrane sample. The cell is filled with a $0.05 \mathrm{~mol} \mathrm{~L}^{-1} \mathrm{NaC} 1$ solution. The electrical resistance of the cell was measured with and without a membrane separating the two chambers. The membrane resistance was then calculated from the difference of the two measurements using the equation 2 ,

$\mathrm{R}_{\mathrm{m}}=\mathrm{R}_{1}-\mathrm{R}_{2}$

where $R_{m}$ is the area resistance of the membrane per unit area, $R_{1}$ the total resistance of the cell and the membrane, and $R_{2}$ the mean resistance of the cell.

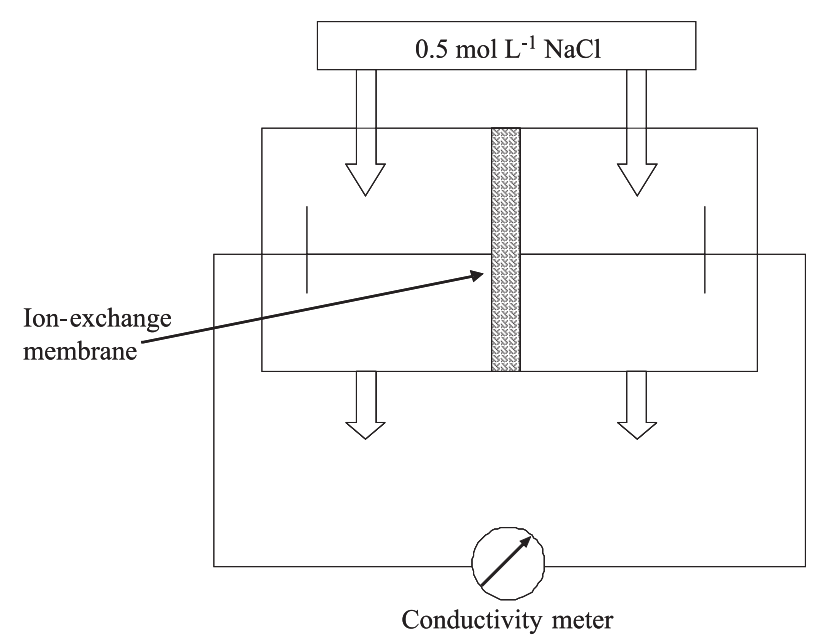

Figure 2. Schematic diagram of the test cell used to determine the electrical resistance of ion-exchange membranes.

\section{Determination of the membrane permselectivity}

The permselectivity was determined by a static method, which is illustrated in Figure 3. The actual test system consisted of two cells separated by the membrane sample. The potential difference across the membrane between two solutions of different concentrations was determined using calomel electrodes. The selectivity was then calculated from the ratio of the experimentally determined to the theoretically calculated potential difference for a $100 \%$ permselective membrane. The theoretical potential difference in the system used during this study was $36.94 \mathrm{mV}$. It was calculated using the following equation 3 ,

$\Delta \mathrm{E}_{\text {th }}=-\frac{\mathrm{RT}}{\mathrm{F}} \ln \frac{\mathrm{M}_{2} \mathrm{~F}_{2}}{\mathrm{M}_{1} \mathrm{f}_{1}}$

where $\mathrm{R}$ is the gas constant, $\mathrm{T}$ the absolute temperature, $\mathrm{F}$ the Faraday constant, $\mathrm{M}_{1}$ and $\mathrm{M}_{2}$ the concentrations (mol L ${ }^{-1}$ ) and $\mathrm{f}_{1}$ and $\mathrm{f}_{2}$ the activity coefficients of the two solutions separated by the membrane.

The permselectivity of the membrane is given by equation 4 ,

$\mathrm{S}=\frac{\Delta \mathrm{E}_{\text {exp }}}{\Delta \mathrm{E}_{\mathrm{th}}} \times 100$

where $\Delta \mathrm{E}_{\text {exp }}$ is the potential difference between the two electrolytes and $\Delta \mathrm{E}_{\text {th }}$ the theoretical potential difference calculated using equation 3 . The membranes were storaged at $60{ }^{\circ} \mathrm{C}$ in $2 \mathrm{~mol} \mathrm{~L}^{-1} \mathrm{NaOH}$ and $2 \mathrm{~mol} \mathrm{~L}^{-1} \mathrm{HCl}$ until the determination of membrane permselectivity.

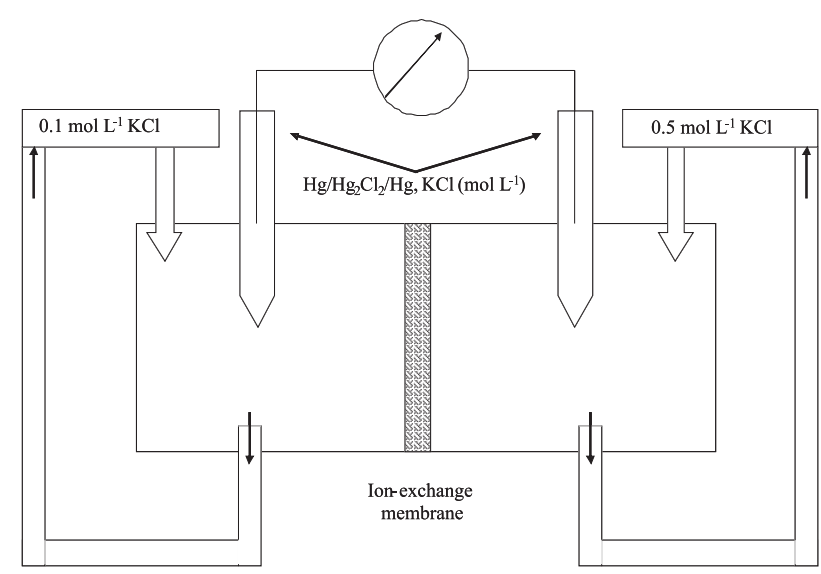

Figure 3. Diagram of the test cell used to determine the permselectivity of ion-exchange membranes.

\section{Determination of the coion fluxes}

The schematic diagram to the experiment for determining the flows of $\mathrm{Na}^{+}$and $\mathrm{Cl}^{-}$ions through a BMP is indicated on Figure 4. During current flow hydrogen ions were generated at the anode, and were converted to hydrogen gas at the cathode. Also hydrogen ions carried almost the entire current across the cation exchange membrane. Therefore if the BMP had operated at $100 \%$ current efficiency, the hydrogen ion and hydroxyl ion concentrations would have remained constant in the measured times. In fact the acidities and alkalinities of the fluids declined with time, as the current efficiencies of the bipolars were less than $100 \%$, there being small leakage flows of $\mathrm{Na}^{+}$and $\mathrm{Cl}^{-}$coions across the bipolar membrane. 
These coion flows were estimated by measuring the rates of accumulation of the ions in the various compartments during current flow. In this case, the current was applied until at least 0.006 equiv. of charge had crossed the membrane. The acid and alkalin solutions were then withdrawn from their compartments and analyzed for $\mathrm{Na}^{+}$ and $\mathrm{Cl}^{-}$ions respectively.

\section{Determination of the water splitting capacity of bipolar membranes}

The water splitting capacity of the BMP was determined in an electrodialysis stack consisting of 6 individual cells, as indicated in the schematic diagram of Figure 5. The effective membrane area, i.e., the cell cross section, was $100 \mathrm{~cm}^{2}$. The distance between the two membranes was $0.2 \mathrm{~cm}$. The two cells containing the electrodes were separated from the other cells by cation-exchange membranes and rinsed with a $0.5 \mathrm{~mol} \mathrm{~L}^{-1} \mathrm{Na}_{2} \mathrm{SO}_{4}$ solution to avoid penetration of chloride ions to the anode and, thus, the formation of chlorine. A $1 \mathrm{~mol} \mathrm{~L}^{-1} \mathrm{HCl}$ solution was recirculated through the cells adjacent to the BMP while a $1 \mathrm{~mol} \mathrm{~L}^{-1}$ $\mathrm{NaCl}$ solution was fed into the outside cells. The protons generated in the BMP form hydrochloric acid in the cell at the cation-exchange side of the BMP with the chloride ions permeating the anion-exchange membrane from the $1 \mathrm{~mol} \mathrm{~L}^{-1} \mathrm{NaCl}$ solution in the adjacent cell. Similarly the hydroxyl ions form sodium hydroxide with the sodium ions transferred through the cation-exchange membrane from the $1 \mathrm{~mol} \mathrm{~L}^{-1} \mathrm{NaCl}$ feed solution. The concentrations and, thus, the production of hydrochloric acid and sodium hydroxide were determined by $\mathrm{pH}$ measurements.

The current efficiency was calculated from the total current passing through the cell system and the measured acid and base concentrations. The potential drop across the BMP was measured with Pt electrodes as a function of the current density.

\section{Determination of membrane stability}

To determine the stability of the membranes at high and low $\mathrm{pH}$ values membrane samples were stored for 7 days at $50{ }^{\circ} \mathrm{C}$ in solutions of $2 \mathrm{~mol} \mathrm{~L}^{-1} \mathrm{NaOH}$ and $2 \mathrm{~mol} \mathrm{~L}^{-1} \mathrm{HC} 1$, respectively. Furthermore, samples were dried for 7 days at $75^{\circ} \mathrm{C}$ over phosphorous pentoxide and rewetted to determine the effect of drying on membrane performance. Changes in the electrical properties and in visual appearance as compared to the original samples were determined.

\section{Results and Discussion}

\section{Membrane ion-exchange capacities}

The ion-exchange capacities of the bipolar membrane made are shown on Table 1.

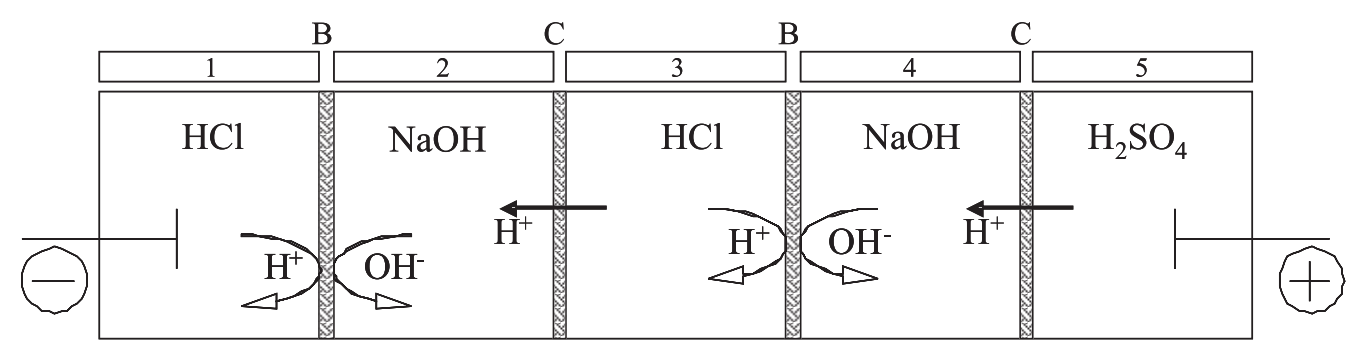

Figure 4. Static cell used for membrane characterization studies (B = bipolar membrane; $\mathrm{C}=$ cation exchange membrane).

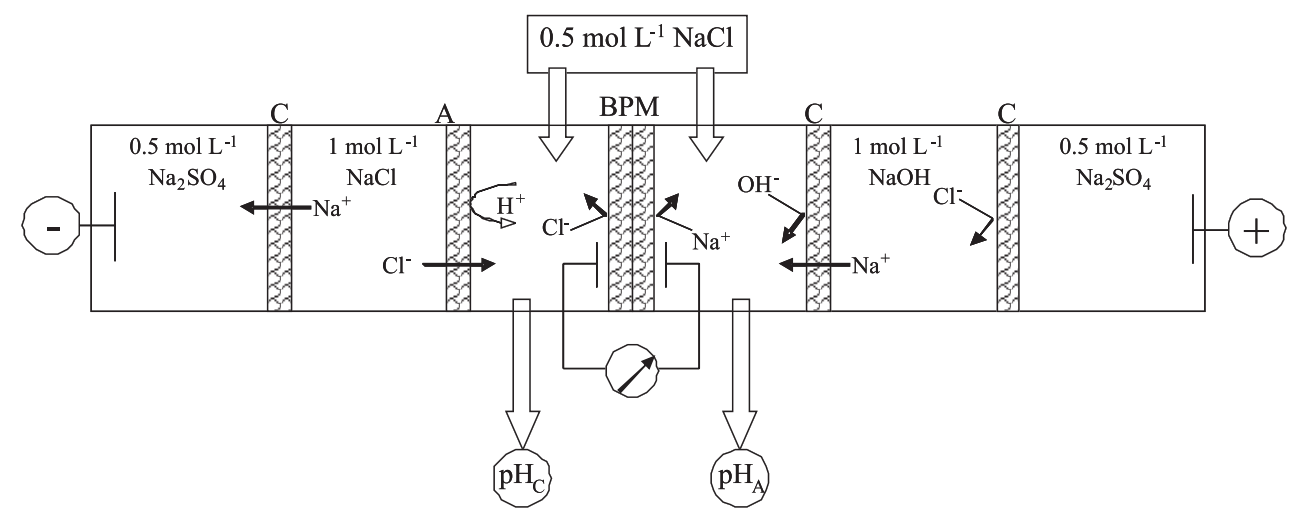

Figure 5. Cell with recirculating flows used for membrane stability studies $(\mathrm{B}=$ bipolar membrane; $\mathrm{C}=$ cation exchange membrane; $\mathrm{A}=$ anion exchange membrane). 
Table 1. Properties of cation- and anion-exchange membranes

\begin{tabular}{lcc}
\hline $\begin{array}{l}\text { Membrane } \\
\left.\text { capacity / (mequiv. } \mathrm{g}^{-1}\right)\end{array}$ & $\begin{array}{c}\text { Ion exchange } \\
\text { water / (\%) }\end{array}$ \\
\hline $\begin{array}{lc}\text { Wition exchange membrane } \\
\text { Without treatment }\end{array}$ & 12.3 \\
Acid treatment (T1) & 0.77 & 13.1 \\
Alkaline treatment (T2) & 1.24 & 15.2 \\
Anion exchange membrane & & 24.4 \\
Without treatment & 1.31 & 16.9 \\
Acid treatment (T1) & 0.33 & 10.8 \\
Alkaline treatment (T2) & 0.59 & \\
\hline
\end{tabular}

The cation-exchange membranes did not show any difference between the initial value (ion-exchange capacities without treatment) and the ion-exchange capacities after two days storage in acid or alkaline solution. On the other hand, the anion-exchange membranes show some differences between the initial values and the ion-exchange capacities after two days storage in acid or alkaline solution. The ion-exchange capacity of a membrane as well as its swelling increased with increasing the basicity of the amine.

\section{Membrane swelling}

The determinations of the degree of swelling membrane are summarized on Table 1. For the membrane PVA/PASA, the swelling degree was $12.3 \%$, while for the PVA/PDDAB, the swelling degree was $24.4 \%$, these results are in agreement with the ion-exchange capacities; for the membrane PVA/PASA, the ion-exchange was 0.77 mequiv. $\mathrm{g}^{-1}$ and for PVA/PDDAB, the ion-exchange capacities was 1.31 mequiv. $\mathrm{g}^{-1}$.

\section{Membrane electrical resistance}

The electrical resistance and the permselectivity of the membrane are a function of its ion-exchange capacity. Drying and extensive exposure at $50{ }^{\circ} \mathrm{C}$ to $2 \mathrm{~mol} \mathrm{~L}^{-1} \mathrm{HCl}$ did not have any effect on the electrical properties or the mechanical stability of the membranes (treatment 1 , T1); treatment with $2 \mathrm{~mol} \mathrm{~L}^{-1} \mathrm{NaOH}$ at $50{ }^{\circ} \mathrm{C}$ also had little effect on the electrical properties (treatment 2, T2). The electrical resistance is slightly increased and the selectivity decreased (Table 2). Figure 6 gives voltage current measurements in $1 \mathrm{~mol} \mathrm{~L}^{-1} \mathrm{HCl} / 1 \mathrm{~mol} \mathrm{~L}^{-1}$ $\mathrm{NaOH}$ for PVA/PASA-PVA/PDDAB BMP with both treatments.

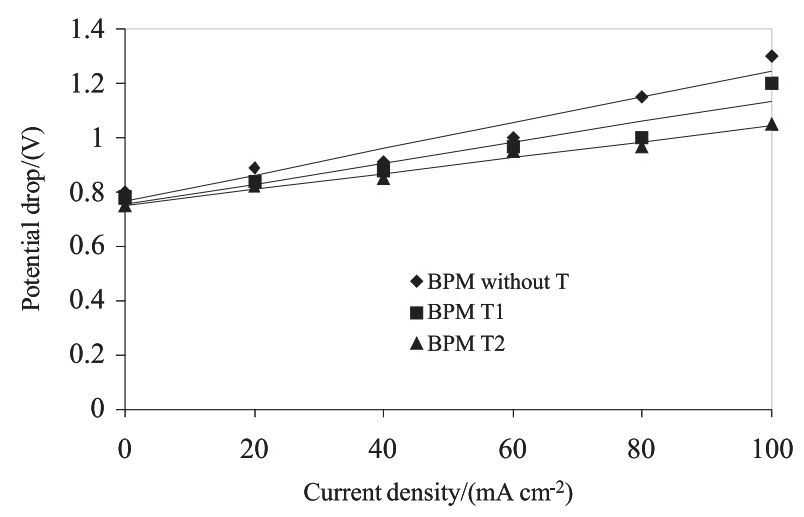

Figure 6. Voltage-current characteristics for bipolar membrane in $1 \mathrm{~mol} \mathrm{~L}^{-1} \mathrm{HCl} / 1 \mathrm{~mol} \mathrm{~L}^{-1} \mathrm{NaOH}$ at room temperature.

It is seen that the PVA/PASA-PVA/PDDAB T1, has the lower electrical resistance. Nevertheless the other membrane (PVA/PASA-PVA/PDDAB T2) possesses certain advantages. Their current efficiencies are higher than that of the PVA/PASA-PVA/PDDAB T1. After the treatment 2, the PVA/PASA-PVA/PDDAB T2 become destroyed.

Table 2. Resistances of cation- and anion-exchange membranes

Area resistance / $\left(\Omega \mathrm{cm}^{-2}\right)$

\begin{tabular}{|c|c|c|c|c|}
\hline Membrane & Initial value & $\begin{array}{c}\text { After drying } \\
\left(7 \text { days at } 75^{\circ} \mathrm{C}\right)\end{array}$ & $\begin{array}{c}\mathrm{T} 1\left(7 \text { days at } 50{ }^{\circ} \mathrm{C},\right. \\
\left.2.0 \mathrm{~mol} \mathrm{~L}^{-1} \mathrm{HCl}\right)\end{array}$ & $\begin{array}{l}\mathrm{T} 2\left(7 \text { days at } 50{ }^{\circ} \mathrm{C}\right. \\
\left.2.0 \mathrm{~mol} \mathrm{~L}^{-1} \mathrm{NaOH}\right)\end{array}$ \\
\hline \multicolumn{5}{|c|}{ Cation exchange membrane } \\
\hline PVA/PASA 1 & 1.20 & 1.15 & 1.00 & 1.40 \\
\hline PVA/PASA 2 & 0.90 & 0.89 & 0.85 & 1.00 \\
\hline PVA/PASA 3 & 0.85 & 0.83 & 0.80 & destroyed \\
\hline \multicolumn{5}{|c|}{ Anion exchange membrane } \\
\hline PVA/PDDAB 1 & 1.30 & 1.80 & 1.38 & 2.50 \\
\hline PVA/PDDAB 2 & 1.03 & 1.30 & 1.00 & 1.50 \\
\hline PVA/PDDAB 3 & 1.17 & 1.40 & 1.10 & destroyed \\
\hline
\end{tabular}


The decrease in resistance in the PVA/PASA membrane is probably related to a hydration effect, either at the interface of the fixed charge regions or else in the interior of monopolar membrane.

\section{Membrane permselectivity}

The membrane permselectivity results are showing in Table 3. The experiments involved the routine testing of PVA/ PASA-PVA/PDDAB BMP which separated $2 \mathrm{~mol} \mathrm{~L}^{-1} \mathrm{NaOH}$ and $2 \mathrm{~mol} \mathrm{~L}^{-1} \mathrm{HCl}$ solutions, in the static cell of Figure 4, at a current of $100 \mathrm{~mA} \mathrm{~cm}^{-2}$. During these experiments we regularly observed that over a period of $24 \mathrm{~h}$ the volume of solution in the acid compartment 1 of the cell would decrease by 1.8-2.2 $\mathrm{mL}$ while that in the alkaline compartment would increase by the same reason. Both the volume of water which would have been split in the BMP during this period and the volume which would have entered compartment 2 in the form of hydrogen and hydroxyl ions were about $1.2 \mathrm{~mL}$. Further, there was no significant accumulation of aqueous ions in compartment 1 , the hydrogen ions converted to gas at the cathode being compensate for by hydrogen ions entering the compartment from the bipolar membrane. It followed, therefore, that there must have been a net flow of $0.4-0.8 \mathrm{~mL}$ of water across the bipolar from the acid compartment 1 to the alkaline compartment 2 , and about $1.2 \mathrm{~mL}$ across PVA/PASA membrane into alkaline compartment 2 . The volume flow across the PVA/PASA membrane corresponds on average to approximately one water molecule for each proton that traversed the PVA/PASA membrane.

\section{Coion flux and current efficiency}

Figure 7, gives the flux data for sodium and chloride ions in the case of both PVA/PASA-PVA/PDDAB T1 and $\mathrm{T} 2$, membrane for different applied currents at room temperature, when the membrane separated $1 \mathrm{~mol} \mathrm{~L}^{-1} \mathrm{HCl}$ and $1 \mathrm{~mol} \mathrm{~L}^{-1} \mathrm{NaOH}$ solutions. It is seen that the ionic fluxes are similar in size for low applied currents but that chloride accounts for an increasing fraction of the coion transport at higher current densities. There is a diffusive flow of the ions across the membrane, at zero current, due to the concentration gradients for the $\mathrm{HCl}$ and $\mathrm{NaOH}$.

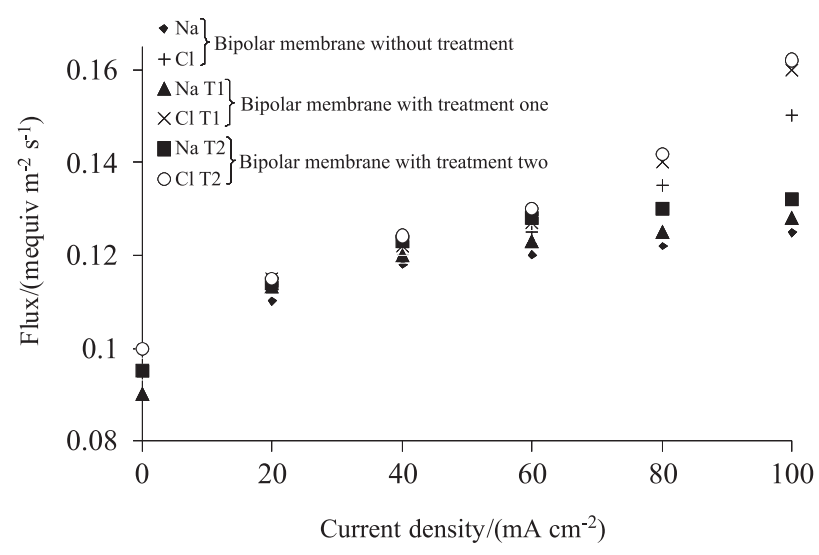

Figure 7. Fluxes of $\mathrm{Na}^{+}$and $\mathrm{Cl}^{-}$ions through bipolar membrane at different current densities. The membrane separated $1 \mathrm{~mol} \mathrm{~L}^{-1} \mathrm{HCl}$ and $1 \mathrm{~mol} \mathrm{~L}^{-1}$ $\mathrm{NaOH}$ solutions, at room temperature.

The data on Figure 7 may be used to calculate the change ion coion flux $\left(\Delta \phi_{\mathrm{i}}\right)$ which results when the current is increased from zero to a value I. These changes can be used to calculate the current efficiency (E) for water splitting, i.e. the fraction of the applied current which is carried by the ions of water. We have equation 5 ,

$\mathrm{E}=\frac{\mathrm{I}-\mathrm{F}\left(\Delta \phi_{\mathrm{Na}}-\Delta \phi_{\mathrm{Cl}}\right)}{\mathrm{I}} \times 100$

where $\mathrm{F}$ is the Faraday constant. However from a practical viewpoint this definition for current efficiency is not the most useful as it ignores the zero current losses of hydrogen, chloride, hydroxyl and sodium ions from the acid and base compartments. It is more convenient to define an effective current efficiency, E' (equation 6),

Table 3. Permselectivity values of cation- and anion-exchange membranes

\begin{tabular}{|c|c|c|c|c|}
\hline \multirow[b]{2}{*}{ Membrane } & \multicolumn{4}{|c|}{ Permselectivity / (\%) } \\
\hline & Initial value & $\begin{array}{c}\text { After drying } \\
\left(7 \text { days at } 75^{\circ} \mathrm{C}\right)\end{array}$ & $\begin{array}{c}\mathrm{T} 1\left(7 \text { days at } 50{ }^{\circ} \mathrm{C}\right. \\
\left.2.0 \mathrm{~mol} \mathrm{~L}^{-1} \mathrm{HCl}\right)\end{array}$ & $\begin{array}{l}\mathrm{T} 2\left(7 \text { days at } 50{ }^{\circ} \mathrm{C}\right. \\
\left.2.0 \mathrm{~mol} \mathrm{~L}^{-1} \mathrm{NaOH}\right)\end{array}$ \\
\hline \multicolumn{5}{|c|}{ Cation exchange membrane } \\
\hline PVA/PASA 1 & 59.3 & 59.5 & 59.7 & 50.1 \\
\hline PVA/PASA 2 & 80.5 & 83.2 & 85.1 & 79.2 \\
\hline PVA/PASA 3 & 94.2 & 94.0 & 93.9 & destroyed \\
\hline \multicolumn{5}{|c|}{ Anion exchange membrane } \\
\hline PVA/PDDAB 1 & 96.6 & 90.2 & 88.4 & 45.5 \\
\hline PVA/PDDAB 2 & 97.5 & 89.9 & 91.2 & 70.7 \\
\hline PVA/PDDAB 3 & 97.0 & 94.8 & 92.0 & destroyed \\
\hline
\end{tabular}


$E^{\prime}=\frac{I-F\left(\phi_{\mathrm{Na}}-\phi_{\mathrm{Cl}}\right)}{\mathrm{I}} \times 100$

where $\phi_{\mathrm{Na}}$ and $\phi_{\mathrm{Cl}}$ are the true fluxes of sodium and chloride through the membrane. The effective current efficiency for the PVA/PASA-PVA/PDDAB T1 is about $1.5 \%$ lower than the true current efficiency for the $1 \mathrm{~mol} \mathrm{~L}^{-1} \mathrm{HCl} / 1 \mathrm{~mol} \mathrm{~L}^{-1}$ $\mathrm{NaOH}$ case at $100 \mathrm{~mA} \mathrm{~cm}^{-2}$; and for the PVA/PASAPVA/PDDAB T1 is about $2 \%$ lower than the true current efficiency for the $1 \mathrm{~mol} \mathrm{~L}^{-1} \mathrm{HCl} / 1 \mathrm{~mol} \mathrm{~L}^{-1} \mathrm{NaOH}$ case at $100 \mathrm{~mA} \mathrm{~cm}^{-2}$.

Figure 8 gives the effective current efficiency data for the case where the membranes separated $1 \mathrm{~mol} \mathrm{~L}^{-1} \mathrm{HCl}$ and $1 \mathrm{~mol} \mathrm{~L}^{-1} \mathrm{NaOH}$ solutions at room temperature. The current efficiency declined with current density from $98 \%$ at $100 \mathrm{~mA} \mathrm{~cm}^{-2}$ to $85 \%$, at $20 \mathrm{~mA} \mathrm{~cm}^{-2}$ for PVA/PASAPVA/PDDAB T1; on the other hand, the current efficiency declined with current density from $96 \%$ at $100 \mathrm{~mA} \mathrm{~cm}^{-2}$ to $88 \%$, at $20 \mathrm{~mA} \mathrm{~cm}^{-2}$ for PVA/PASA-PVA/PDDAB T2.

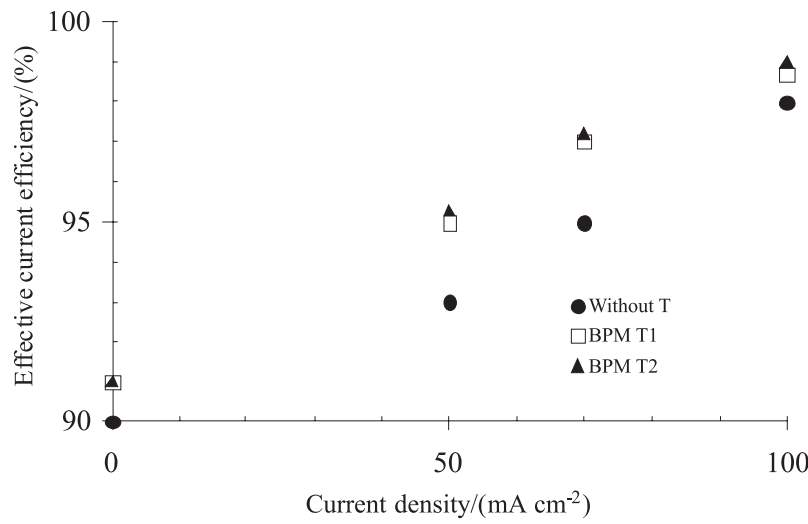

Figure 8. Effective current efficiency (E') of a bipolar membrane with and without treatment, at different membrane currents. The membrane separated $1 \mathrm{~mol} \mathrm{~L}^{-1} \mathrm{HCl} / 1 \mathrm{~mol} \mathrm{~L}^{-1} \mathrm{NaOH}$ solutions at room temperature.

Figure 9 shows the variations in $\mathrm{Na}^{+}$and $\mathrm{Cl}^{-}$ion fluxes with external acid and base concentration when the current was $100 \mathrm{~mA} \mathrm{~cm}^{-2}$. There was a 10 fold increase in the total coion flux and a decrease in effective current efficiency from $99 \%$ to $85 \%$ (T1) and $99 \%$ to $89 \%$ (T2), when the external $\mathrm{NaOH}$ and $\mathrm{HCl}$ concentrations were raised from $0.5 \mathrm{~mol} \mathrm{~L}^{-1}$ to $4 \mathrm{~mol} \mathrm{~L}^{-1}$.

Figure 10 shows the Arrhenius plots of flux vs reciprocal temperature for the $1 \mathrm{~mol} \mathrm{~L}^{-1} \mathrm{HCl} / 1 \mathrm{~mol} \mathrm{~L}^{-1} \mathrm{NaOH}$ case at $100 \mathrm{~mA} \mathrm{~cm}^{-2}$. Increasing the temperature caused an increase in the coion flux, particularly for $\mathrm{Na}^{+}$ions. The slopes correspond to activation energies of $7.4 \mathrm{kcal} \mathrm{mol}^{-1}$ for $\mathrm{Na}^{+}$and $5.8 \mathrm{kcal} \mathrm{mol}^{-1}$ for $\mathrm{Cl}^{-}$(T1); and for T2, the activation energies of $7.0 \mathrm{kcal} \mathrm{mol}^{-1}$ for $\mathrm{Na}^{+}$and $6.1 \mathrm{kcal} \mathrm{mol}^{-1}$ for $\mathrm{Cl}^{-}$.

The membrane appeared to have stable operating characteristics in acids and alkalis solutions for the range of

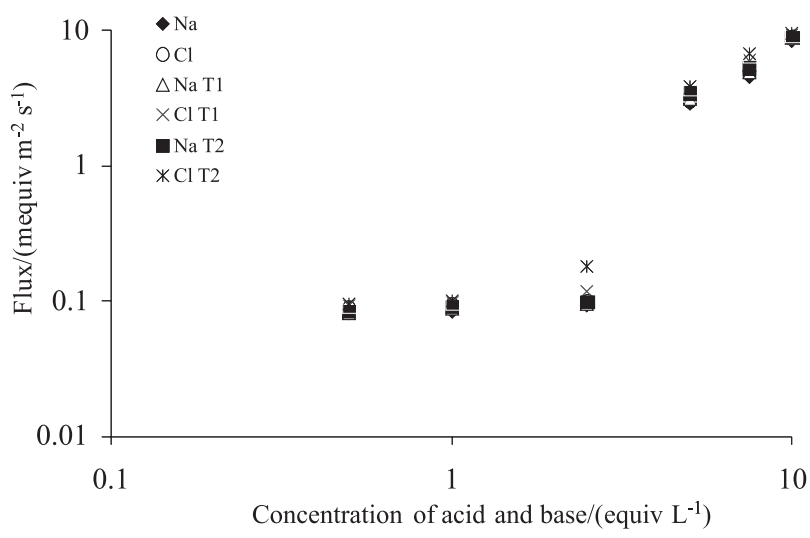

Figure 9. $\mathrm{Na}^{+}$and $\mathrm{Cl}^{-}$ion flux data for different acid/base concentrations at room temperature. The current density was $100 \mathrm{~mA} \mathrm{~cm}^{-2}$.

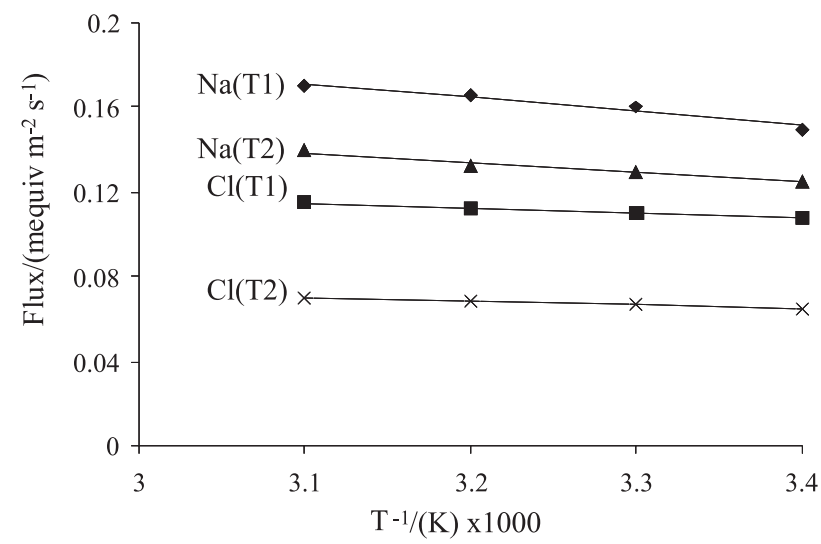

Figure 10. $\mathrm{Na}^{+}$and $\mathrm{Cl}^{-}$ion fluxes versus reciprocal temperature for PVA/PASA-PVA/PDDAB T1 and PVA/PASA-PVA/PDDAB T2 bipolar membranes separating $1 \mathrm{~mol} \mathrm{~L}^{-1} \mathrm{HCl} / 1 \mathrm{~mol} \mathrm{~L}^{-1} \mathrm{NaOH}$ solutions. The current density was $100 \mathrm{~mA} \mathrm{~cm}^{-2}$.

concentrations that were investigated, i.e. up to $10 \mathrm{~mol} \mathrm{~L}^{-1}$ $\mathrm{NaOH}$ and $6 \mathrm{~mol} \mathrm{~L}^{-1} \mathrm{HCl}$, provided that there was an applied electric current. However the performance deteriorated if they separated acid and alkaline solution for an excessive period, without an applied current. For instance the PVA/ PASA-PVA/PDDAB T1 deteriorates in performance if the adjacent compartments contain $2 \mathrm{~mol} \mathrm{~L}^{-1} \mathrm{NaOH}$ and $2 \mathrm{~mol} \mathrm{~L}^{-1} \mathrm{HCl}$ and the current is discontinued for about $60 \mathrm{~h}$. The absence of the $\beta-\mathrm{C}$ atom in the amine, makes this amine less sensitive to hydrolytical degradation. On the other hand, the membranes are stable for at least six months when there is no applied current, it they separate dilutes solutions, i.e. $<0.5 \mathrm{~mol} \mathrm{~L}^{-1} \mathrm{NaCl}$.

\section{Conclusions}

The present report describes the preparation of bipolar membrane in which the separate anion and cation exchange membranes were fused together in a hydraulic press at $160{ }^{\circ} \mathrm{C}$ at a pressure of $2.76 \mathrm{MPa}$ to form a two ply membrane structure. The effects of acid and alkaline 
post-treatment were investigated. The electrical resistance of the bipolar membrane formed by this methodology was slightly increased, while the selectivity decreased. The membrane permselectivity of the bipolar membrane did not change with the acid or alkaline post-treatment. On the other hand, increasing the temperature caused an increase in the $\mathrm{Na}^{+}$coion flux (activation energy $6.4 \mathrm{kcal} \mathrm{mol}^{-1}$ for T1, $6.0 \mathrm{kcal} \mathrm{mol}^{-1}$ for T2). However, increasing in the temperature caused a decrease in the $\mathrm{Cl}^{1-}$ coion flux (activation energy $3.8 \mathrm{kcal} \mathrm{mol}^{-1}$ for T1, $5.1 \mathrm{kcal} \mathrm{mol}^{-1}$ for T2). The membranes also have the advantage that the water splitting properties are not altered if the films become dry. Furthermore, they are fairly robust and are simple to produce.

\section{Acknowledgments}

Financial support from Consejo Nacional de Ciencia y Tecnología (CONACYT) under the "Apoyo complementario para investigadores en proceso de consolidación SNI 1" is gratefully acknowledged.

\section{References}

1. Frilette, V. J.; J. Phys. Chem. 1956, 60, 435.

2. Rose, W. H.; Millar, I. F.; Ind. Eng. Chem. Fundam. 1986, 25, 360.

3. Bassignana, I. C.; Reiss, H.; J. Membr. Sci. 1983, 15, 27.

4. Wilhelm, F. G.; van der Vegt, N. F. A.; Strathmann, W. H.; J. Electroanal. Chem. 2001, 502, 152.

5. Wilhelm, F. G.; Pünt, I.; van der Vegt, N. F. A.; Strathmann, W. H.; Wessling, M.; Ind. Eng. Chem. Res. 2002, 41, 579.

6. Mauro, A.; Biophys. J. 1962, 2, 179.

7. Costers, H. J. L.; Biophys. J. 1965, 5, 669.

8. Simons, R.; Desalination 1979, 28, 41.

9. Yokoyama, Y.; Tanioka, A.; Miyasaka, K.; J. Membr. Sci. 1988, 38, 223.

10. Bauer, B.; Gerner, F. J.; Strathmann, H.; Desalination 1988, 68, 279.

11. Mani, K. H.; Byszcwski, C. H.; Abstract of AIChE Spring National Meeting, Houston TX, USA, 1987.

12. Chiao, Y. C.; Chlanda, F. P.; Mani, K. N.; J. Membr. Sci. 1991, $61,239$.

13. Bolton, H. R.; J. Chem. Technol. Biotechnol. 1992, 54, 341.

14. Raucq, D.; Pourcelly, G.; Gavach, C.; Desalination 1993, 91, 163.

15. Novalic, S.; Okwor, J.; Kulbe, K. D.; Desalination 1996, 105, 277.

16. Mani, K. N.; J. Membr. Sci. 1991, 58, 117.

17. Urairi, M.; Tsuru, T.; Nakao, S.; Kimura, S.; J. Membr. Sci. 1992, 70, 153.
18. Strathmann, H.; Rapp, H. J.; Bauer, B.; Bell, C. M.; Desalination 1993, 90, 303.

19. Ramirez, P.; Aguilella, V. M.; Manzanares. J. A.; Mafé, S.; J. Membr. Sci. 1992, 73, 191.

20. Sokirko, A. V.; Ramirez, P.; Manzanares, J. A.; Mafé, S.; Ber. Bunsen Phys. Chem. 1993, 97, 1040.

21. Ramirez, P.; Rapp, H. J.; Mafé, S.; Bauer, B.; J. Electroanal. Chem. 1994, 375, 101.

22. El Moussaoui, R.; Pourcelly, G.; Maeck, M.; Hurwitz, H. D.; Gavach, C.; J. Membr. Sci. 1994, 90, 283.

23. Aritomi, T.; van der Boomgaard, Th.; Strathmann, H.; Desalination 1996, 101, 13.

24. Mafé, S.; Ramirez, P.; Acta Polym. 1997, 48, 234.

25. Strathmann, H.; Krol, J. J.; Rapp, H. J.; Eigenberger, G.; J. Membr. Sci. 1997, 125, 123.

26. Shimizu, K.; Tanioka, A.; Polymer 1977, 38, 5441.

27. Chou, T. J. Tanioka, A.; J. Phys. Chem. B 1998, 102, 7866.

28. Chamoulaud, G.; Belanger, D.; J. Colloid Interface Sci. 2005 , $281,179$.

29. Higuchi, A.; Nakagawa, T.; J. Chem. Soc., Faraday Trans. 1 1989, 85, 3609.

30. Higa, M.; Kira, A.; J. Phys. Chem. B 1995, 99, 5089.

31. Ramírez, P.; Mafé, S.; Manzanares, J. A.; Pellicer, J.; J. Electroanal. Chem. 1996, 404, 187.

32. Tanioka, A.; Shimizu, K.; Miyasaka, K.; Zimmer, H. J.; Minoura, N.; Polymer 1996, 37, 1883.

33. Higa, M.; Tanioka, A.; Kira, A.; J. Phys. Chem. B 1997, 101, 2321.

34. Chilcott, T. C.; Coster, H. G. L.; George, E. P.; J. Membr. Sci. 1995, 100, 77.

35. Chilcott, T. C.; Coster, H. G. L.; George, E. P.; J. Membr. Sci. 1995, 108, 185.

36. Alcaraz, A.; Ramírez, P.; Mafé, S.; Holdik, H.; J. Phys. Chem. B 1996, 100, 15555.

37. Alcaraz, A.; Ramírez, P.; Manzanares, J. A.; Mafé, S.; J. Phys. Chem. B 2001, 105, 11669.

38. Chilcott, T. C.; Chan, M.; Gaedt, L.; Nantawisarakul, T.; Fane, A. G.; Coster, H. G. L.; J. Membr. Sci. 2002, 195, 153.

39. Gaedt, L.; Chilcott, T. C.; Chan, M.; Nantawisarakul, T.; Fane, A. G.; Coster, H. G. L.; J. Membr. Sci. 2002, 195, 169.

40. Huang, Ch.; Xu, T.; Environ. Sci. Technol. 2006, 40, 5233.

41. Simons, R.; J. Membr. Sci. 1993, 82, 65.

42. Simons, R.; J. Membr. Sci. 1993, 78, 13.

43. Simons, R.; Electrochim. Acta 1984, 29, 151.

44. Simons, R.; Electrochim. Acta 1985, 30, 275.

45. Mackie, J. S.; Meares, P.; Proc. R. Soc. London 1955, 232 , 498A.

Received: September 22, 2008 Web Release Date: June 12, 2009 